\title{
Embroidery Art in the Southwest Region of Kyrgyzstan
}

\section{Rakhima Abdyrasulova1, Gulnara Maksytova1, Kimiya Torogeldieva1, Rano Mamaturdieva1, Akinai Kushbakova1, Zura Turdubaeva ${ }^{2}$, Zhypargul Abdullaeva ${ }^{3 *}$ (i)}

\author{
${ }^{1}$ Department of Arts, Osh State University, Osh, Kyrgyzstan \\ ${ }^{2}$ Department of drawing, sketching and labor, Osh State University, Osh, Kyrgyzstan \\ ${ }^{3}$ Science and Research Department, Osh State University, Osh, Kyrgyzstan \\ Email: ^jypar.science@oshsu.kg
}

How to cite this paper: Abdyrasulova, R., Maksytova, G., Torogeldieva, K., Mamaturdieva, R., Kushbakova, A., Turdubaeva, Z., \& Abdullaeva, Z. (2021). Embroidery Art in the Southwest Region of Kyrgyzstan. Art and Design Review, 9, 263-267.

https://doi.org/10.4236/adr.2021.93021

Received: June 14, 2021

Accepted: July 26, 2021

Published: July 29, 2021

Copyright $\odot 2021$ by author(s) and Scientific Research Publishing Inc. This work is licensed under the Creative Commons Attribution International License (CC BY 4.0).

http://creativecommons.org/licenses/by/4.0/

\begin{abstract}
This article is focused on research results on the embroidery art preservation as a national heritage in the southwest region of Kyrgyzstan. The study results were obtained based on school extracurricular activities, field and ethnographic materials. Embroidery ornamentation has its own history, which is characterized by particular nation's lifestyle routines. Embroidery is one form of folk art. In historical times, embroidery was a women's craft, which is kept and exchanged from grandmothers' generation to their daughters. In Kyrgyzstan, girls have been involved in embroidery art since childhood, as it was the necessity for keeping comfort at home, family and prepare embroidery for dowry gifts. Embroidery ornamentation like other forms of folk art reflects the nomadic lifestyle and our people's profession. Research aim in this work is to introduce students with traditional Kyrgyz embroidery types and their use purposes in various situations such as weddings, home decoration, bride dowry items preparation, etc. Teach girls to embroider in the classroom and in extracurricular activities.
\end{abstract}

\section{Keywords}

Embroidery, Art, National Culture, Heritage, Crafts

\section{Introduction}

The embroidery art has deep historical roots and lives among the people to these days and in all regions of the republic, embroidery is very widespread and considered quite common for women, starting from an early age (Ashurov \& Uralova, 2018). Embroidery is an art requiring not only skill but also persistence; women always like beautiful, when they embroider, they transform household 
items (Efimova, 2014). Techniques of artistic embroidery are very diverse, artistic embroidery occupies a special place in the fabric decoration; the thing decorated by embroidery acquires artistic value (Kamneva \& Shvetsova, 2018). Embroidery is performed by decorative needlecraft using yarn or thread on canvas or fabric (The Spruce Crafts, 2021).

In the Kyrgyz nomadic lifestyle, embroidery is used to decorate the interior and exterior of the yurt, a blanket was placed on the edge of a yurt to keep the house warm and clean. The yurt is decorated with small embroidered items, embroidered felt, crockery bags, spoon bags, scissor bags, mirror bags, teapot bags, clothes (Abdyrasulova, 2021; Koponova \& Abdyrasulova, 2016; Abdyrasulova \& Koponova, 2017; Akmataliev, 1996), clothes bags, closed heads, outside the doors, and other similar embroidered items.

National costumes and hats were also decorated with embroidery: belts, takya, duria, and men's leather pants (Kapalbaev, 2016). At weddings, the bride's horse saddle is embroidered with various embroideries: sweaters, gowns, blankets, the bride's veil, takya, vests, belts, aprons, and the groom's clothes (Kadyrov, 2012).

Kyrgyz embroidery can be divided into two main complexes: northern and southern. The northern embroidery is characterized by felt, hanging shelves, shoes, bags, women's clothing, belts, colors. Negative boats were mainly used to decorate the art, using loops. And in the south, the most widely embroidered items are pillows, rugs with right stitching and embroidered headwear takiya with a negative boat stitch.

The main types of Kyrgyz embroidery (Figure 1) include:

1) negative boat;

2) negative boat from the inside out;

3) half cross;

4) crawl;

5) Bulgarian cross;

6) hook;

7) sewing (with a needle);

8) ilmedos;

9) proper needlework;

10) and 11) basma;

12) multiple.

The national artistic style is a vivid expression in embroidery art as it shows both color ratios in ornament variations; this type of applied art is a valuable source for identifying the distinctive features and studying culture (Antipina, 1962).

\section{Research Methods and Materials}

In this work research was conducted based on the collection of information about ethnographic embroidery materials in Kadamzhai region of Kyrgyzstan. Historical origin and purpose of embroidery items were analyzed. Basic types of embroidery and embroidery items used in the nomadic lifestyle were described. Importance of obtaining embroider skills for girls was noted. 


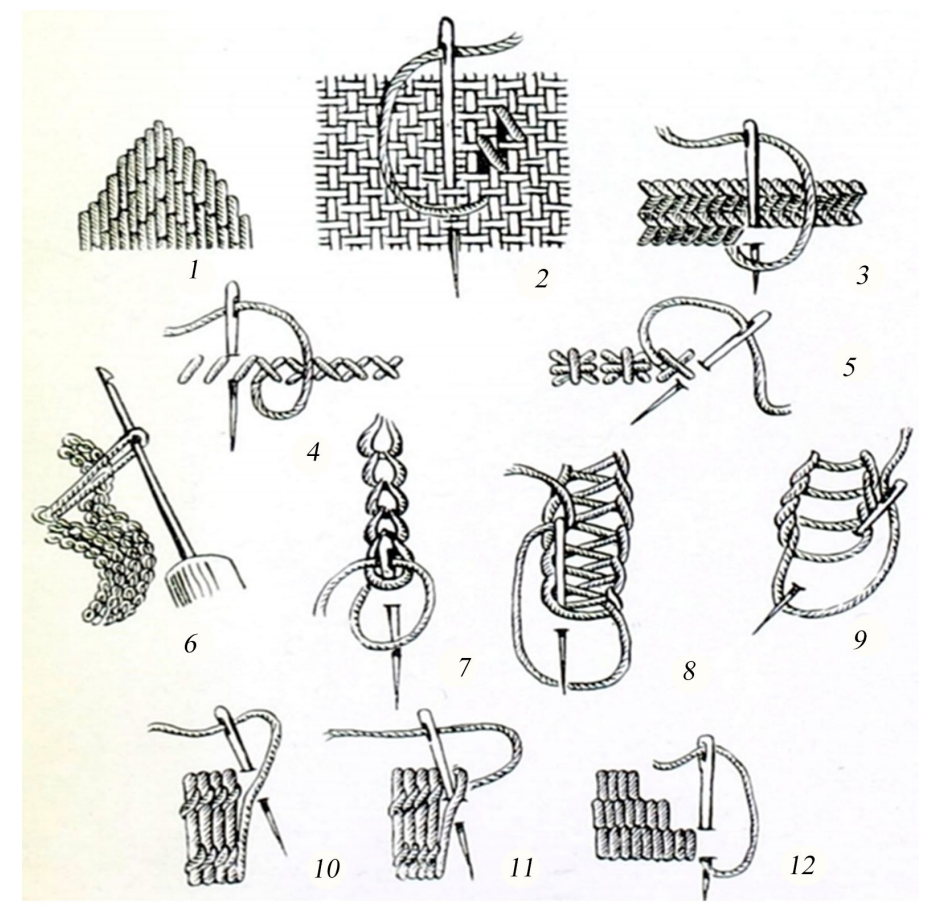

Figure 1. Main types of embroidery.

\section{Embroidery Items}

Each region has its own peculiarities influenced by the local conditions, professions, and the nation culture. In Kadamzhai region, informants shared with embroidery art works keeping in their homes, such as felts (south), pillows, rugs, and embroidered handkerchiefs. National handicrafts are becoming more and more valued, for example, takiya of the Makiya Zulaika, who was born and raised in the Karagansai pasture in Kadamzhai district was received when she got married. Alibekova Kairinsa, a resident of Kara-Jygach village in the same district, left the takiya to her daughter-in-law, and today her granddaughter, Tamara Sultanova, a resident of Aravan district, keeps it. The hat was relatively sewn in the 1900s. Kep takiya is called as a duria presented to Aidai, daughter of Rahmatilla, a resident of Kara-Jygach village in the area. Duriya kept by Gulsava Shakirova, a granddaughter from Markaz village.

Blanket cover and handkerchiefs were made in 1964 by Saliya Amizaveva, a resident of Kara-Jygach village who was born in 1936.

Tradition of sewing pillows (Figure 2 and Figure 3) and other items for girls is necessary in Kyrgyz people culture. Addition of embroidery class to the school curriculum is important for keeping the national culture.

While teaching girls embroidery in classroom, we saw that they sewed with great interest and were interested in the embroidery history. Embroidery in the labor class teaches girls to know the national culture, to concentrate, to be thrifty, patient, and to perceive beauty and keep national heritage, as heritage education can enable social empowerment (Yan \& Chiou, 2021). Curricula organization to accommodate science and arts, drawing with pedagogy associated with 


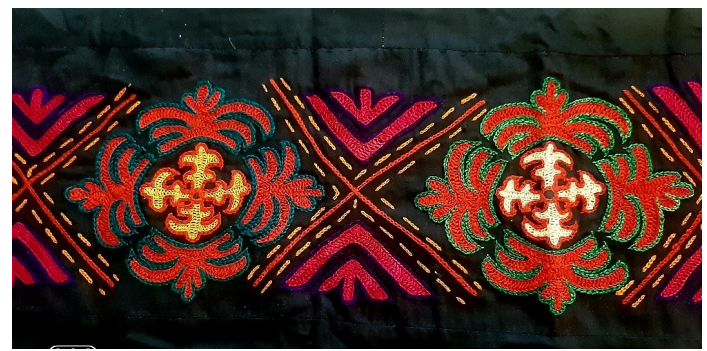

Figure 2. Embroidery used for decorating pillow.

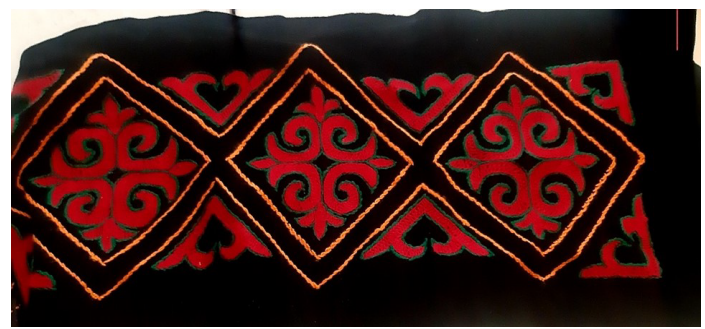

Figure 3. Embroidery for decorating supportimg pillow.

arts fruitful ways offer to engage students in school classroom (Braund \& Reiss, 2019). School lessons in learning lace, knitting or embroidery will eventually develop girls' professional activity and can become the income source; these skills will remain "family helpers" for girls in their adult life (Kormilitsyna, 2013). For the effective organization of training and education, process in the girls' class based on the personality oriented pedagogical technologies (Efimenko \& Tarakanova, 2014). In creating an artwork, color and form are main variables in the painting code, appealing students' emotions and skills in participating in communication (Caiman \& Jakobson, 2019).

\section{Conclusion}

In order to preserve our national culture, it is necessary to add embroidery class to the school curriculum for developing girls craft making skills. Through our national handicrafts, we can prove and keep our Kyrgyz culture. While teaching girls embroidery in the school classroom, we saw that they sewed with great interest to the history of embroidery. Embroidery teaches students to know the national culture, to concentrate, to be thrifty, patient, and to perceive beauty.

\section{Conflicts of Interest}

The authors declare no conflicts of interest regarding the publication of this paper.

\section{References}

Abdyrasulova, R. R. (2021). Student's Scientific Society: Problem of Artistic and Musical Education. In E. D. Bashkaeva, \& G. G. Tenyukova (Eds.), ELECTRONIC Collection of Scientific Articles (192 p). Chuvash State Pedagogical University.

Abdyrasulova, R. R., \& Koponova, A. S. (2017). Reconstruction of National Kyrgyz Cos- 
tume for Girls by XIX to XX Century's Technology. Bulletin of Kyrgyz State University of Building, Transport and Architecture Named after N. Isanov, 2, 83-87.

Akmataliev, A. S. (1996). Kyrgyz Trade Handicrafts (328 p). Kyrgyzstan.

Antipina, K. (1962). Features of Material Culture and Applied Art of Southern Kyrgyz (223 p). Publishing House of the Academy of Sciences of the Kyrgyz SSR.

Ashurov, M. D., \& Uralova N. S. (2018). Criteria for Evaluating Educational and Creative Activities of Younger Schoolchildren in the Classroom of National Decorative Embroidery: Scientific Notes of the Khujand State University Named after Academician B. Gafurov. Humanities, 2, 247-253.

Braund, M., \& Reiss, M. J. (2019). The 'Great Divide': How the Arts Contribute to Science and Science Education. Canadian Journal of Science, Mathematics and Technology Education, 19, 219-236. https://doi.org/10.1007/s42330-019-00057-7

Caiman, C., \& Jakobson, B. (2019). The Role of Art Practice in Elementary School Science. Science \& Education, 28, 153-175. https://doi.org/10.1007/s11191-019-00036-2

Efimenko, V. N., \& Tarakanova, N. V. (2014). Features of the Organization of the Educational Process at School, Taking into Account the Psychophysical Characteristics of Girls. Bulletin KRAUNZ. Humanities, 2, 95-98. https://doi.org/10.12737/5542

Efimova, L. V. (2014). Embroidery as an Aesthetic Element of a Costume. Service Plus, 8, 89-93.

Kadyrov, V. V. (2012). Saima Kyrgyz Embroidery (56 p). Raritet Publishing House.

Kamneva, S. Y., \& Shvetsova, O. V. (2018). Types of Embroidery and Its Application in a Modern Costume. Traditional Applied Arts and Education, 4, 128-135.

Kapalbaev, O. E. (2016). Epic "Manas" and the Leather Craft of the Kyrgyz. Scientific Journal, 6, 75-80.

Koponova, A. S., \& Abdyrasulova, R. R. (2016). Traditional Clothing Kyrgyzstan Citizens, Their Historical Feature of Traditional Men's and Woman Trousers (Dambal, Sharovar). Actual and Scientific Research in Modern World, 10, 77-84.

Kormilitsyna, M. Y. (2013). Labor Lessons Are Life Lessons. Lifelong learning: Continuing Education for Sustainable Development, 11, 329-330.

The Spruce Crafts (2021). Embroidery. https://www.thesprucecrafts.com/embroidery-4162905

Yan, W.-J., \& Chiou, S.-C. (2021). The Safeguarding of Intangible Cultural Heritage from the Perspective of Civic Participation: The Informal Education of Chinese Embroidery Handicrafts. Sustainability, 13, 4958. https://doi.org/10.3390/su13094958 